\title{
A DINOSAURIAN NECROPOLIS: JURASSIC RESEARCH AND INTERPRETATION AT DINOSAUR NATIONAL MONUMENT (UT/CO), USA
}

\author{
CHURE, Daniel J., Dinosaur National Monument, Box 128, Jensen, UT 84035
}

The dinosaur quarry at Dinosaur National Monument has yielded an abundant and diverse Late Jurassic terrestrial megavertebrate fauna. Between its discovery in 1909 and the cessation of excavations in 1923, over 350 tons of dinosaur bones were collected and shipped to the Carnegie Museum. At present, some 1500+ bones are preserved in-situ in the Quarry, which is enclosed within a glass walled Visitor Center. The quarry attracts several hundred thousand visitors a year.

For many years the emphasis of the paleontology program at DNM has been the development of the in-situ dinosaur bone exhibit. Over the last decade emphasis has switched to the broader issues of managing the ancient ecosystem buried in the rocks of the Late Jurassic Morrison Formation. This work has uncovered a rich record of microvertebrates, pollen, invertebrates, trace fossils, and new dinosaurs, including eggshell fragments and an embryo. At the same time, stratigraphic, sedimentologic, and isotopic dating has provided insight into the environments and duration of the Morrison ecosystem.

This research is presented to the public through diverse media, including public programs, park newspaper, museum exhibits, television and magazine interviews, videotapes, and compact disks. The interpretation to the public emphasizes that research on dinosaurs and the world they lived in is a dynamic enterprise where exciting discoveries continue to be made. 